\title{
Effect of Genetic Variation on the Tryptic Hydrolysis of Bovine $\beta$-Lactoglobulin A, B, and C
}

\author{
L. K. Creamer, ${ }^{1}$ H. C. Nilsson, ${ }^{2}$ M. A. Paulsson, ${ }^{2}$ C. J. Coker, ${ }^{1}$ \\ J. P. Hill, ${ }^{1}$ and R. Jiménez-Flores ${ }^{3}$ \\ ${ }^{1}$ Fonterra Research Centre, P.O. Box 11 029, Palmerston North, New Zealand \\ ${ }^{2}$ Department of Food Engineering, Lund University, SE-22100, Lund, Sweden \\ ${ }^{3}$ Dairy Products Technology Center, California Polytechnic State University, \\ San Luis Obispo 93407
}

\section{ABSTRACT}

The structure, stability, and hydrolysis characteristics of $\beta$-lactoglobulin (LG) A are different from those of either $\beta$-LG B or $\beta$-LG C. Purified samples of these proteins were hydrolyzed with trypsin and the rates of loss of native monomeric $\beta$-LG structure were measured using sodium dodecyl sulfate PAGE. At the same time, the appearance of many individual peptides were identified and followed in time by HPLC, measuring their concentration as a function of solution $\mathrm{pH}$, temperature, protein concentration, and added urea or palmitate. The identity of the peptides was confirmed by liquid chromatography-mass spectrometry. This semiquantitative exploration showed that the rate of hydrolysis was in the order $\beta$-LG A $>\beta$-LG B $>\beta$-LG C under most circumstances, and that 12 of the 18 trypsin-susceptible bonds were cleaved at very similar rates that were governed by the variant type. Consequently, the rate of hydrolysis of the intact protein was related to the overall structural stability of the individual proteins and the accessibility of certain peptide bonds to the enzyme. The hydrolysis of mixtures of 2 or more variants or of denatured $\beta$-LG gave more heterogeneous peptide mixtures.

(Key words: $\beta$-lactoglobulin, tryptic hydrolysis, genetic variant, kinetics)

Abbreviation key: DTT = dithiothreitol, E:S = enzyme:substrate, $\mathbf{R P}=$ reversed-phase, $\mathbf{T F A}=$ trifluoroacetic acid.

\section{INTRODUCTION}

Whey protein concentrates are used as food ingredients because of their functional properties as well as their nutritional properties. The major protein of bovine

Received June 15, 2004.

Accepted July 22, 2004

Corresponding author: R. Jiménez-Flores; e-mail: rjimenez@ calpoly.edu. whey is $\beta$-LG, which is responsible for many of the functional properties of whey protein products (Mulvihill and Kinsella, 1987). In some instances, these functionalities can be enhanced by heat treatments or by partial hydrolysis to mixtures of large peptides (Turgeon et al., 1992; Chen et al., 1994; Huang et al., 1996; Caessens et al., 1999a, 1999b). Additionally, the hydrolyzates themselves are used as ingredients for processed foods.

Bovine $\beta$-LG occurs naturally in a number of genetically different variants, which differ from one another by substitutions of one or more amino acids within the protein sequence. The most common variants are known as $\beta$-LG $\mathrm{A}$ and $\beta$-LG B; additionally, $\beta$-LG C occurs in milk in both New Zealand (Hill et al., 1996) and Australia (McLean et al., 1984) at moderate frequencies (Farrell et al., 2004). It has been reported that $\beta$-LG A is hydrolyzed by papain (Schmidt and van Markwijk, 1993), chymotrypsin (Motion and Hill, 1994; Van Willige and FitzGerald, 1995), V8 protease (Caessens et al., 1999b), plasmin (Caessens et al., 1999a), and trypsin (Monnot and Yon, 1964; Huang et al., 1994a, 1994b; Motion and Hill, 1994; Van Willige and FitzGerald, 1995; Caessens et al., 1999b) more rapidly than is $\beta$-LG $\mathrm{B}$, and a preliminary note indicates that $\beta$-LG C is hydrolyzed more slowly than $\beta$-LG B by trypsin and chymotrypsin (Motion and Hill, 1994; Hill et al., 1996).

Although there have been many studies of the functional properties of $\beta$-LG hydrolyzates, only a few have looked at differences between the $\mathrm{A}$ and $\mathrm{B}$ variants, and none has examined $\beta$-LG C. Huang et al. (1994b) compared the size and the rate of formation of peptides of $\beta$-LG A and $\beta$-LG B and found that the initial peptide release was different for the 2 variants. They also found that there was a difference in size distribution of the peptides of $\beta$-LG A and $\beta$-LG B.

The hydrolysis of $\beta$-LG has been studied using a range of techniques. These include the increase in $\mathrm{N}$ terminal amino groups (Monnot, 1964; Van Willige and FitzGerald, 1995); SDS-PAGE, which can show the rate 
of loss of the intact protein (Schmidt and van Markwijk, 1993) and can indicate the existence of large peptides (Huang et al., 1994a, 1996); size-exclusion HPLC in acetonitrile solution, which can show the reduction in size of groups of peptides (Hill et al., 1996); and reversed-phase (RP)-HPLC, which can be used to separate most of the peptides in the hydrolyzate from one another (Dalgalarrondo et al., 1992; Dufour et al., 1994; Otte et al., 1997). When RP-HPLC is coupled with mass spectrometry, the identity of the peaks can often be ascertained without resorting to traditional sequencing methods (Caessens et al., 1999a; Chevalier et al., 2002; Imre et al., 2003; Schilling et al., 2003).

In the present study, we used SDS-PAGE of reduced samples to show the effects of temperature, protein concentration, and $\mathrm{pH}$ on the relative rates of loss of $\beta$-LG $\mathrm{A}, \beta$-LG B, and $\beta$-LG C. We also used RP-HPLC with a C2-C18 column to show the differences in the peptide patterns given by the 3 variant proteins.

\section{MATERIALS AND METHODS}

\section{Materials}

$\beta$-Lactoglobulin A, B, and $\mathrm{C}$ were prepared as described earlier (Manderson et al., 1998). 1-L-Tosylamide-2-phenylethyl chloromethyl ketone-treated trypsin (Cat. No. T-1426), DL-dithiothreitol (DTT) (Cat. No. D6032), and 2-mercaptoethanol were obtained from Sigma Chemical Co. (St. Louis, MO). The electrophoresis chemicals were obtained from Bio-Rad Laboratories (Hercules, CA). All other chemicals were from BDH Laboratory Supplies (Poole, England) and were at least AnalaR grade.

\section{Protein Hydrolysis}

Samples ( $3 \mathrm{~mL}$ ) of purified $\beta$-LG A, B, and C, at a concentration of $1.4 \%(\mathrm{wt} / \mathrm{vol})$, were mixed with $3 \mathrm{~mL}$ of $100 \mathrm{~m} M$ Tris-HCl buffer, $\mathrm{pH} 7.5,8.1,8.4$, and 8.7, which lowered the $\mathrm{pH}$ values to $7.24,7.85,8.31$, and 8.58 , respectively, and $5 \mathrm{~mL}$ of the mixture was put into a plastic tube and cooled to $20^{\circ} \mathrm{C}$ or warmed to 37 , 47 , or $57 \pm 0.1^{\circ} \mathrm{C}$ in a temperature-controlled water bath. A $350-\mu \mathrm{L}$ aliquot of $0.1 \%$ (wt/vol) trypsin solution was added at an enzyme:substrate (E:S) ratio of 1:100 (wt/wt) for the first $3 \mathrm{pH}$ trials and an $\mathrm{E}: \mathrm{S}$ ratio of 1:200 $(\mathrm{wt} / \mathrm{wt})$ for the last trial $(\mathrm{pH}$ 8.58) to give a final $\beta$-LG concentration of $6.5 \mathrm{mg} / \mathrm{mL}$. Before addition of enzyme and at various times after addition of enzyme (2.5, 4, $6,9,13,20,30,45,65,100$, and $150 \mathrm{~min}$ ), 2 samples of $200 \mu \mathrm{L}$ were taken for SDS-PAGE and RP-HPLC analysis, respectively. For the high concentration samples, the protein solution was mixed 1:1 with doublestrength buffer and concentrated to $5 \%$ of its original volume by using a stirred ultrafiltration cell fitted with a YM 10 DIAFLO ultrafiltration membrane (Amicon, Inc., Beverly, MA) to obtain solutions with protein concentrations of more than $130 \mathrm{mg} / \mathrm{mL}$. These solutions were subsequently diluted and their $\mathrm{pH}$ was determined; they were then mixed with enzyme solution to give $\beta$-LG concentrations of $122 \mathrm{mg} / \mathrm{mL}$ in the reaction mixture.

The samples for SDS-PAGE analysis were mixed with $1.0 \mathrm{~mL}$ of SDS sample buffer containing $0.13 \mathrm{mg}$ $\mathrm{DTT} / \mathrm{mL}$, boiled for $4 \mathrm{~min}$, and then stored at $4^{\circ} \mathrm{C}$ until analyzed. The samples for RP-HPLC analysis were mixed with $200 \mu \mathrm{L}$ of phosphate buffer ( $26 \mathrm{mM}$ sodium phosphate/68 $\mathrm{m} M \mathrm{NaCl}$ buffer adjusted to $\mathrm{pH} 6.0$ and containing $6.54 \mathrm{mg}$ of DTT/mL), boiled for $4 \mathrm{~min}$, and then mixed $1: 1$ with $200 \mu \mathrm{L}$ of a $5 \%$ acetonitrile, $0.1 \%$ trifluoroacetic acid (TFA) solution and stored at $4{ }^{\circ} \mathrm{C}$ until analyzed.

\section{SDS-PAGE}

The preparation of the gels, loading of samples, electrophoresis, gel staining, destaining, scanning, and band quantitation have been described previously (Manderson et al., 1998). The reaction rates were estimated using Microsoft Excel 97 by regressing the logarithm of band intensity vs. reaction time. The calculations included only band intensity results that were $>10 \%$ of the band intensity of the zero-time sample.

\section{RP-HPLC}

The hydrolyzed protein samples were chromatographed at $0.7 \mathrm{~mL} / \mathrm{min}$ on 2 Pharmacia PepRPC HR 5/ 5 FPLC columns, which contained $120 \AA$ pore-size beads coated with $\mathrm{C} 2-\mathrm{C} 18$ phase (held at $25^{\circ} \mathrm{C}$ with a Timberline TL-50 controller), connected in series using a Waters $600 \mathrm{E}$ system controller and a Waters 700 Satellite Wisp autoinjector. The column effluent was monitored with a Hewlett-Packard 1040A multiwavelength detection system (Hewlett-Packard Co., Camas, WA), and the data were fed to a ChemStation for processing. The eluting solvent sequence was $5 \%$ acetonitrile in $0.1 \%$ TFA for 5 min, followed by a linear gradient from $5 \%$ acetonitrile in $0.1 \%$ TFA to $60 \%$ acetonitrile in $0.1 \%$ TFA over $70 \mathrm{~min}$, followed by $60 \%$ acetonitrile in $0.1 \%$ TFA for $15 \mathrm{~min}$, followed by $5 \%$ acetonitrile in $0.1 \%$ TFA for $15 \mathrm{~min}$.

\section{Liquid Chromatography-Mass Spectrometry}

The peptides were separated by RP-HPLC on a Waters HPLC system (Waters Associates, Millipore Corp., Waters Chromatography Division, MA) Alliance 2690 
Separations Module, which comprised a Waters 486 MS Tunable Absorbance Detector and a Waters 996 Photodiode Array Detector. Signals at 205 and $280 \mathrm{~nm}$ were monitored. The same HPLC columns and method previously described were used in the Waters system. The software used was Waters Millennium version 3.05.01 within a Windows operating system.

The eluting peptides were characterized by mass spectrometry using a Perkin Elmer Sciex (Thornhill, ON, Canada) Triple Quadrupole API 300 LC/MS/MS system. The eluent stream from the Waters HPLC system was split such that approximately 10 to $15 \mu \mathrm{L} / \mathrm{min}$ was introduced into the mass spectrometer using an electrospray Perkin Elmer Sciex API Ion Spray inlet interface. Ions were generated and focused using a positive ion spray voltage of $5600 \mathrm{~V}$ with detection between $\mathrm{m} / z$ values of 200 and $3000 \mathrm{amu}$. Parameters for operation of the mass spectrometer were step size, $0.2 \mathrm{amu}$; dwell time, $0.5 \mathrm{~ms}$; scan time, $7 \mathrm{~s}$; and $25 \mathrm{~V}$. The RNG and IQ2 voltages were ramped from 140 to $280 \mathrm{~V}$ and from -15 to $-90 \mathrm{~V}$, respectively. The mass spectrometer was calibrated using a propylene glycol standard as outlined in the Perkin Elmer Sciex API 300 manual, using MassChrom 1.0 software. The data were analyzed using BioMultiView 1.3.1 (Perkin Elmer Sciex) and the reference mass library used was Peptide Map 2.2 (Perkin Elmer Sciex).

\section{RESULTS}

\section{Loss of Intact Protein using SDS-PAGE}

A typical set of PAGE patterns is shown in Figure 1 for $\beta$-LG A, $\beta$-LG $\mathrm{B}$, and $\beta$-LG $\mathrm{C}$ hydrolyzed at $\mathrm{pH} 7.85$ and $37^{\circ} \mathrm{C}$. The major band was $\beta$-LG, and a sharp minor band with a low mobility was identified as trypsin by using control samples of reduced trypsin heated in SDS buffer. The quantity of bound dye in the $\beta$-LG bands decreased rapidly with time for $\beta$-LG A (Figure 1A), slowly for $\beta$-LG B (Figure 1B), and even more slowly for $\beta$-LG C (Figure 1C). There were no perceptible bands of higher mobility, indicating that there were negligible quantities of high molecular weight peptides as reported by Huang et al. (1994b), Otte et al. (1997), and Maynard et al. (1998). This was probably a consequence of our samples being reduced prior to electrophoresis (whereas their samples contained disulfide-linked peptides) and many susceptible peptide bonds being cleaved at comparable rates.

The estimated changes in the quantity of $\beta$-LG with time are shown in Figure 2, and the estimated lines of best fit used the data between 10 and $100 \%$ of the original $\beta$-LG concentrations. The rate of loss of intact $\beta$ LG A (Figure 2) was greater than those of $\beta$-LG B and $\beta$-LG C. The calculated rate constants $\left(\mathrm{k}_{\mathrm{A}}, \mathrm{k}_{\mathrm{B}}\right.$, and $\left.\mathrm{k}_{\mathrm{C}}\right)$

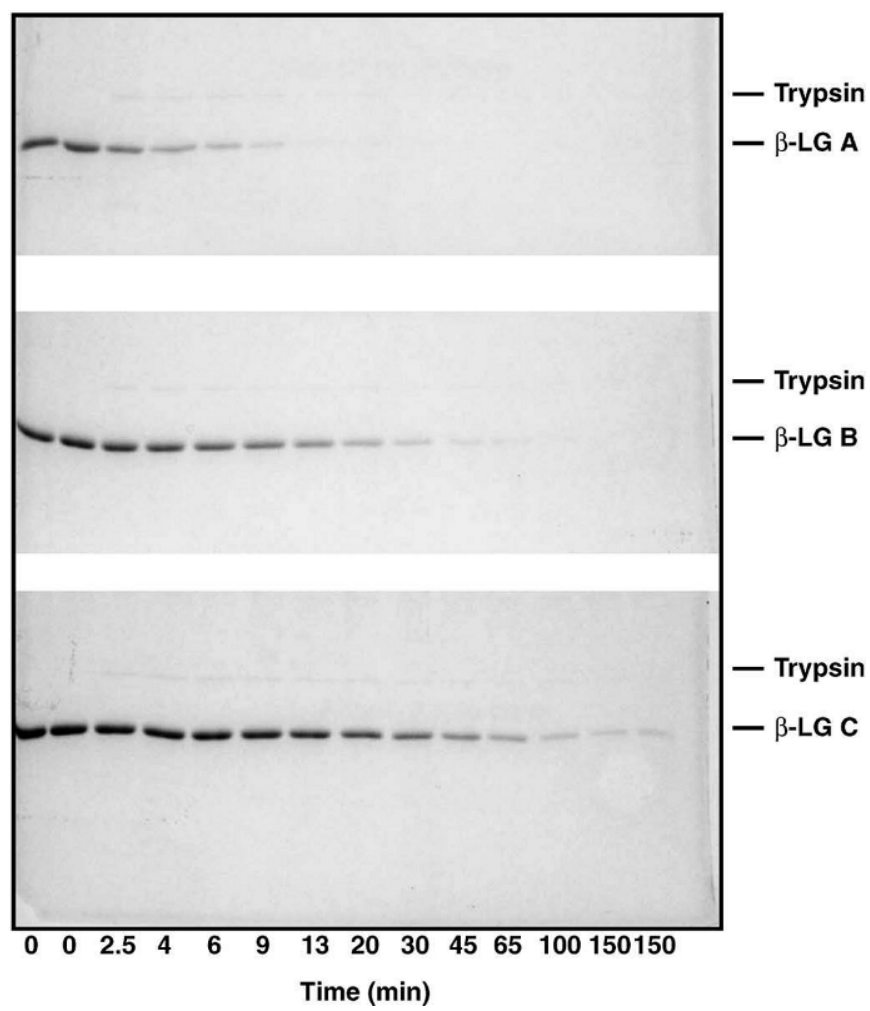

Figure 1. SDS-PAGE patterns of the tryptic hydrolyzates of (A) $\beta$-LG A, (B) $\beta$-LG B, and (C) $\beta$-LG C at $\mathrm{pH} 7.85,37^{\circ} \mathrm{C}$, and an enzyme:substrate ratio of $1: 100$ (wt/wt). Lanes 1 and 2 contain nonhydrolyzed samples; lanes 3 to 12 contain samples after $2.5,4,6,9,13$, $20,30,45,65$, and 100 min of hydrolysis; and lanes 13 and 14 contain final samples after 150 min of hydrolysis.

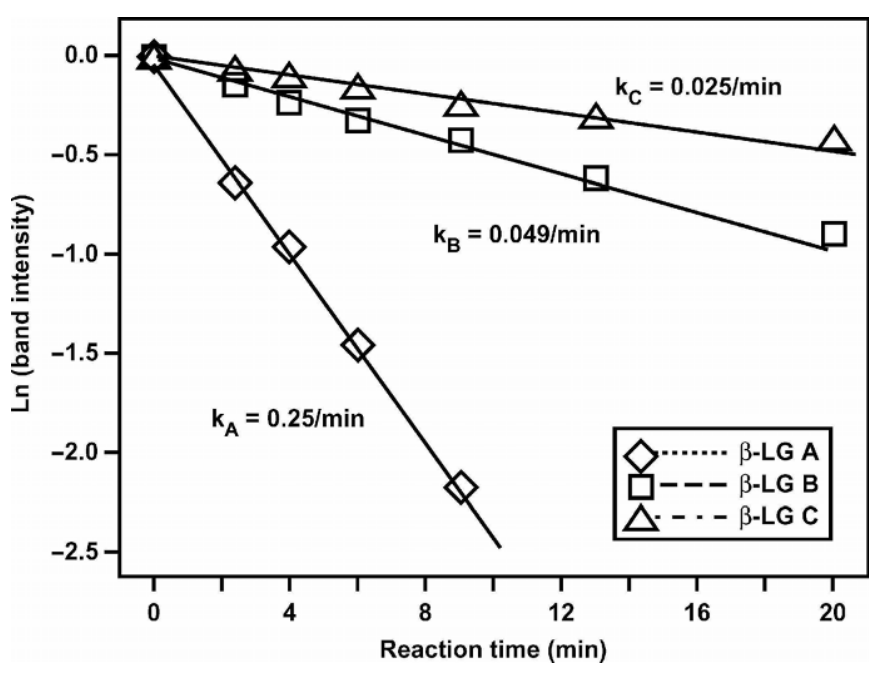

Figure 2. Examples of the estimation of the rates of loss of $\beta$-LG $\mathrm{A}, \mathrm{B}$, and $\mathrm{C}$ during hydrolysis using quantitative data from the SDSPAGE patterns shown in Figure 1. The rate constants were calculated from the slopes of the first 20 min of reaction. 

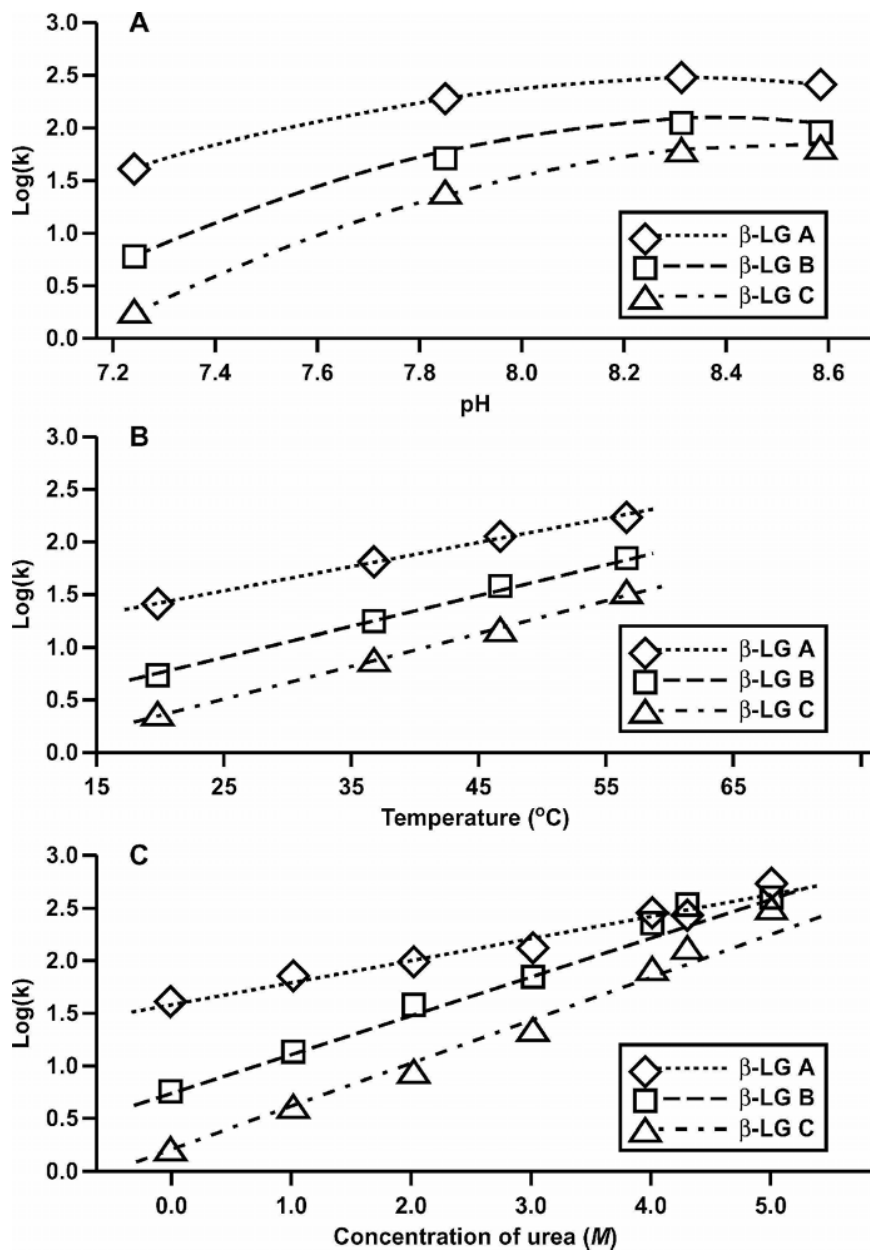

Figure 3. Effect of environmental conditions on the rates of hydrolysis of $\beta$-LG A, $\beta$-LG B, and $\beta$-LG C. A) Effect of reaction pH at $37^{\circ} \mathrm{C}$; B) effect of reaction temperature at $\mathrm{pH} 7.85$; and $\mathrm{C}$ ) effect of urea concentration.

for the loss of the 3 proteins under standard conditions $\left(\mathrm{pH} 7.85, \mathrm{E}: \mathrm{S}\right.$ ratio of $1: 100(\mathrm{wt} / \mathrm{wt}), 37^{\circ} \mathrm{C}$ ) were 250 , 49 , and $25 \times 10^{-3} / \mathrm{min}$ for $\beta$-LG A, $\beta$-LG B, and $\beta$-LG $\mathrm{C}$, respectively.

pH effect. The rates of hydrolysis increased with $\mathrm{pH}$ for all 3 variants between $\mathrm{pH} 7.24$ and 8.31 (Figure $3 \mathrm{~A})$. When the $\mathrm{pH}$ was increased to 8.58 and the E:S ratio was decreased from 1:100 to 1:200 (wt/wt), the rate of hydrolysis for $\beta$-LG A did not change significantly, whereas the rate of hydrolysis decreased for $\beta$-LG B and increased slightly for $\beta$-LG C. This led to $\mathrm{k}_{\mathrm{A}}>\mathrm{k}_{\mathrm{B}}$ $\geq \mathrm{k}_{\mathrm{C}}$ at $\mathrm{pH} 8.58$ instead of $\mathrm{k}_{\mathrm{A}}>\mathrm{k}_{\mathrm{B}}>\mathrm{k}_{\mathrm{C}}$ as found at the lower $\mathrm{pH}$. The rates (Figure $3 \mathrm{~A}$ ) showed a decreasing ratio between $\mathrm{k}_{\mathrm{A}}$ and $\mathrm{k}_{\mathrm{B}}$ from $\mathrm{pH} 7.24$ to 8.31. To examine the ratio of the rate constants, the logarithms of the rate constants were plotted against $\mathrm{pH}$. The ratio between $\mathrm{k}_{\mathrm{B}}$ and $\mathrm{k}_{\mathrm{C}}$ seemed to decrease from $\mathrm{pH} 7.24$ to 7.85 but was nearly constant from $\mathrm{pH} 7.85$ to 8.31 . The ratio between $\mathrm{k}_{\mathrm{B}}$ and $\mathrm{k}_{\mathrm{C}}$ was nearly one at $\mathrm{pH} 8.58$. However, it was not possible to compare this point with the other $\mathrm{pH}$ points because of the different $\mathrm{E}$ :S ratio. The ratio between $\mathrm{k}_{\mathrm{A}}$ and $\mathrm{k}_{\mathrm{C}}$ decreased over the whole $\mathrm{pH}$ interval (7.24 to 8.58). It was expected that this ratio might have changed systematically with $\mathrm{pH}$ because the ratio of monomer to dimer in the mixture would have increased as the $\mathrm{pH}$ increased (Verheul et al., 1999).

Temperature effect. When the temperature of hydrolysis was decreased to $20^{\circ} \mathrm{C}$ and increased to $47^{\circ} \mathrm{C}$, the rate of hydrolysis of $\beta$-LG A, $\beta$-LG $\mathrm{B}$, and $\beta$-LG $\mathrm{C}$ decreased and increased, respectively. Increasing the temperature to $57^{\circ} \mathrm{C}$ also increased the initial rate of loss of $\beta$-LG, much as expected, but the rate of hydrolysis decreased with time. This effect was barely noticeable for $\beta$-LG A, more marked for $\beta$-LG B (not shown), and quite obvious for $\beta$-LG C because less of the protein was hydrolyzed before the enzyme was denatured and became inactive. It was clearly seen on the gels (data not shown) that trypsin started to break down after only $10 \mathrm{~min}$ at $57^{\circ} \mathrm{C}$, probably because of temperatureinduced denaturation and autolysis of the trypsin, which led to incomplete hydrolysis of the protein. Consequently, only the earliest data points were used to derive the rate constants presented in Figure 3B.

To examine the ratio of the rate constants, the logarithms of the rate constants were plotted against temperature (Figure 3B). The slopes of the $\beta$-LG B and $\beta$ LG $C$ lines were very similar, indicating that the ratio of the rate constants was essentially unchanged during the initial stage of hydrolysis and that these proteins behaved similarly. However, the slope of the $\beta$-LG A line appeared to be slightly lower, suggesting that temperature affected this protein differently from $\beta$-LG B and $\beta$-LG C.

Urea effect. Urea affects the way proteins are folded, through alteration of the properties of the aqueous phase. Creamer (1995) showed that $\beta$-LG B was extensively unfolded in about $6 M$ urea at neutral $\mathrm{pH}$, and Cho (2000) showed that the 3 variant proteins were affected similarly. The present results (Figure 3C) show that increasing urea concentration increased the rate of hydrolysis dramatically for $\beta$-LG B and $\beta$-LG C, but less so for $\beta$-LG A. At concentrations above $4 M$, the peptides released were more heterogeneous, possibly because the enzyme was also hydrolyzed (Nilsson, 2000). The differences in rates of hydrolysis between $\beta$-LG A and $\beta$-LG B became quite small as the concentration of urea was increased, suggesting that the differences in the rates of hydrolysis in the absence of urea were caused by structural differences between these 2 proteins, but the differences between $\beta$-LG B and $\beta$-LG $\mathrm{C}$ were minor. 


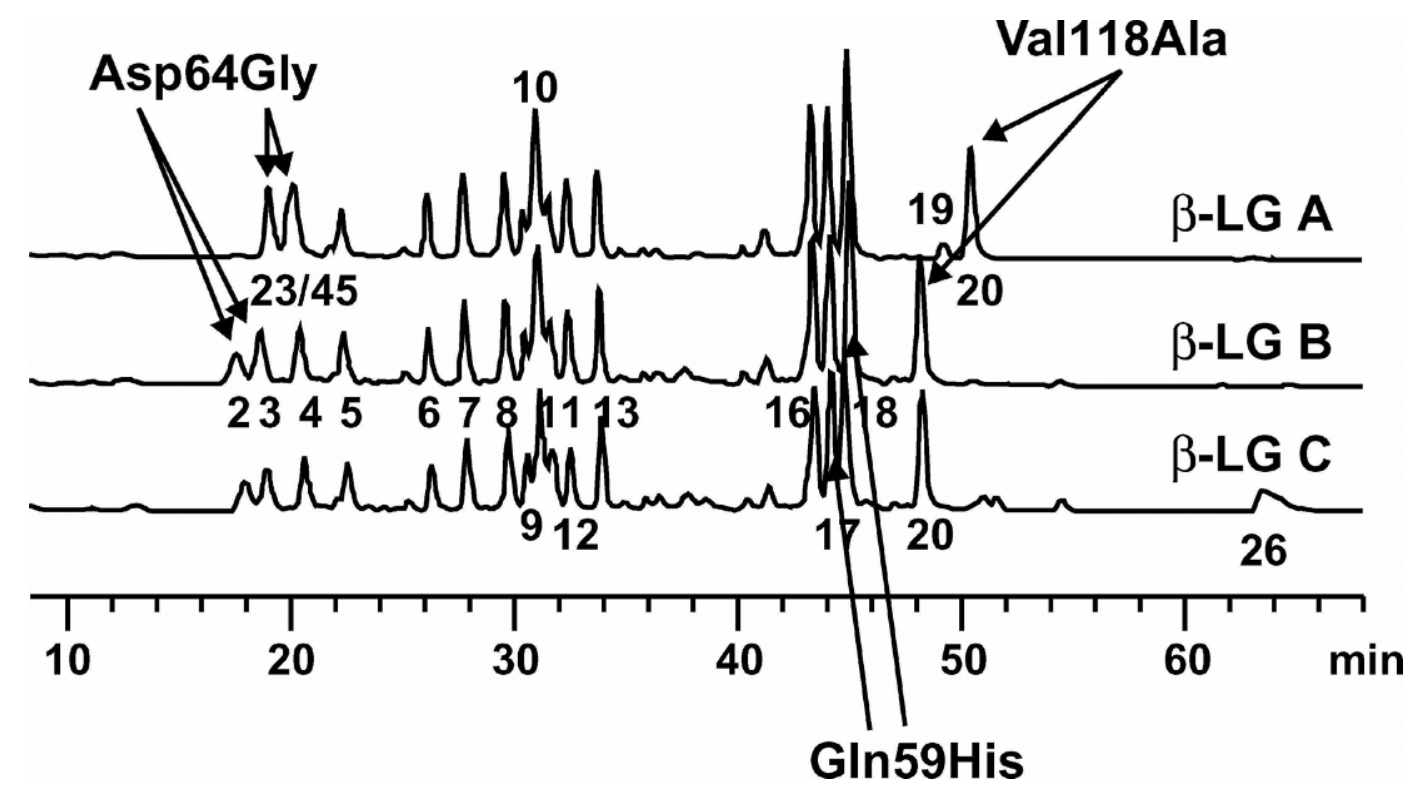

Figure 4. RP-HPLC profiles of tryptic hydrolyzates of $\beta$-LG A, $\beta$-LG B, and $\beta$-LG C. The proteins were hydrolyzed for 150 min at $37^{\circ} \mathrm{C}$ at an enzyme:substrate ratio of 1:100 (wt/wt) and at $\mathrm{pH} 7.85$. The peaks are labeled 1 to 13 and 16 to 26 in the order of elution for $\beta$-LG B. (Description of peptides is presented in Table 1.)

Palmitate effect. The addition of a $2: 1 M$ ratio of palmitic acid to $\beta$-LG A, $\beta$-LG $\mathrm{B}$, and $\beta$-LG $\mathrm{C}$ prior to hydrolysis decreased the rates of hydrolysis to about 5 , 10 , and $10 \%$, respectively. However, the peptide release patterns were not greatly affected, suggesting that there were no specific effects related to the binding of the ligand (Nilsson, 2000).

\section{RP-HPLC of Hydrolyzates and Peptide Identification}

The peaks on the HPLC traces (Figures 4 and 5) were numbered from 1 to 26 (10 to $64 \mathrm{~min}$ ) in order of elution, where peak 26 , which eluted last (62 to $64 \mathrm{~min}$ ), was intact $\beta$-LG. The peptides were identified (Table 1 from Creamer et al., accepted). The HPLC traces in Figure 4 were the 150-min samples from the standard trial, to show the differences between the peptide concentrations in the hydrolyzate profiles when the hydrolysis was essentially complete. There were a few obvious differences among the patterns, which were caused by the amino acid substitutions in the variant proteins. For example, peak 2 (18 min) seemed to be absent from the $\beta$-LG A traces (Figures 4 and 5), and peak 20 eluted at about $50 \mathrm{~min}$ for $\beta$-LG A, but at about $47.5 \mathrm{~min}$ for $\beta$-LG B and $\beta$-LG C. Most significantly, peptides 2 (and 3 ) and 19 (and 20) contained the genetic variations at positions 64 and 118 for $\beta$-LG A (Table 1), and peptide 18 contained the genetic variation at position 64 for $\beta$ LG C. The mobilities of these peaks changed according to the genetic variants (Figure 5; Table 1).
The RP-HPLC traces shown in Figure 5 were selected to show the differences between the patterns normalized to the point when approximately the same amount of intact protein remained in the hydrolysis reaction. In Figure 5A, about $20 \%$ of the intact protein remained; in Figure 5B, only 1 to $2 \%$ of the intact protein remained. It can be seen that peaks 21,22 , and 23 were much larger in the $\beta$-LG A hydrolyzate regardless of the extent of hydrolysis, but most noticeably at the end of the reaction (Figure 5B). These peptides have been identified as Val41-Lys70, Val41-Lys69, and Val15Arg40, respectively (Nilsson, 2000).

It is also clear from Figures 4 and 5, especially Figure $5 \mathrm{~A}$, that, at comparable extents of loss of $\beta$-LG, the hydrolysis profiles for $\beta$-LG $\mathrm{B}$ and $\beta$-LG $\mathrm{C}$ were more similar to one another than to the hydrolysis profile for $\beta$-LG A.

\section{Rates of Hydrolysis of Peptide Bonds}

The areas of the individual peaks on the HPLC traces, at either 280 or $205 \mathrm{~nm}$, were used to analyze the rate at which each peptide was released (Nilsson, 2000). Surprisingly, most peptide bonds were cleaved at a very similar rate, but this rate was dependent on which variant was hydrolyzed (as expected from the loss of native protein discussed earlier (e.g., Figure 1). All of the Arg$\mathrm{X}$ bonds were cleaved rapidly, and Lys8-Gly9, Lys14Val15, Lys75-Thr76, Lys139-Ala140, and Lys138Ala139 were also cleaved rapidly (Figure 6). The 2 Lys- 


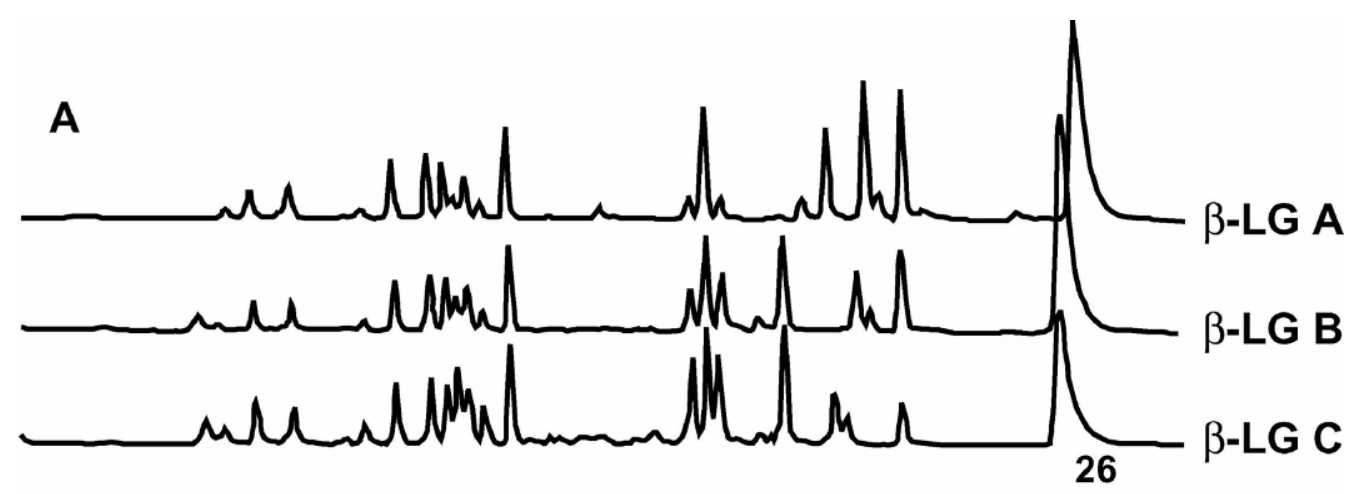

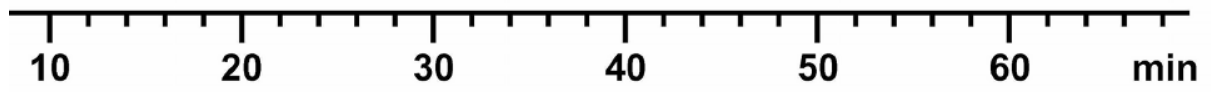

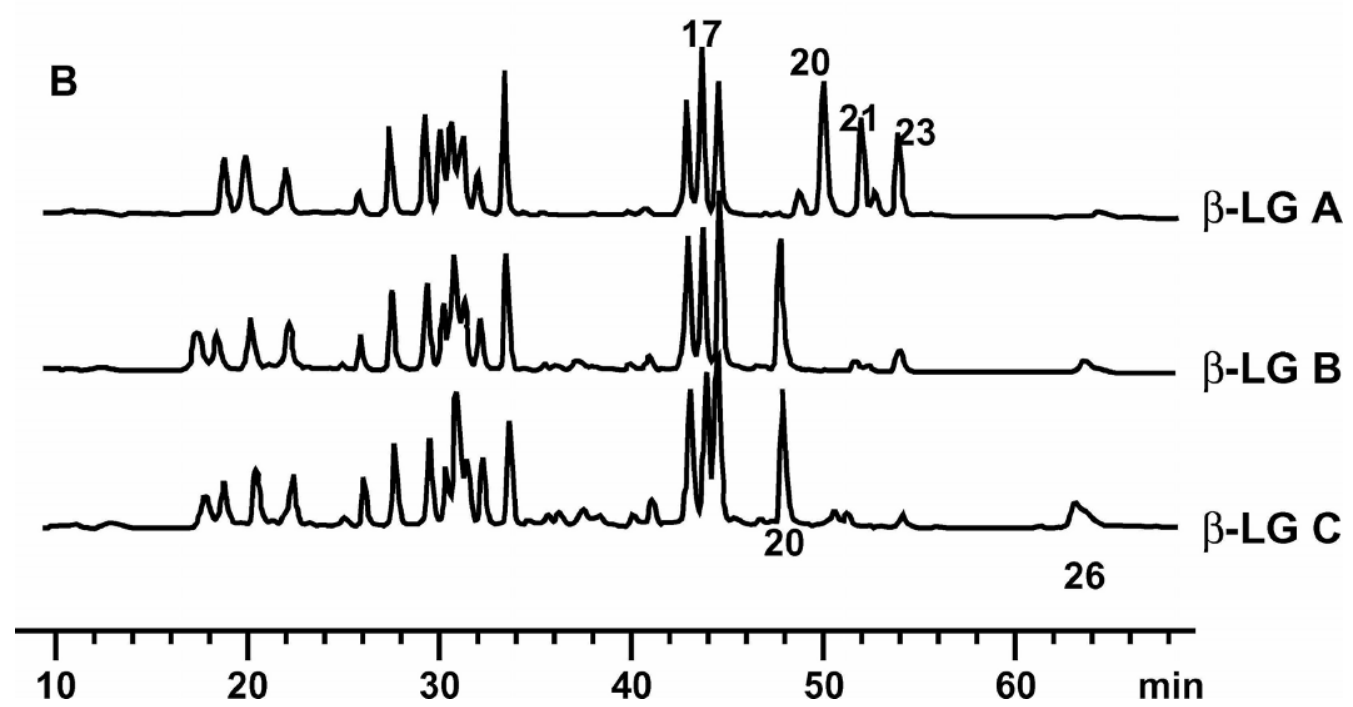

Figure 5. RP-HPLC profiles of tryptic hydrolyzates of $\beta$-LG A, $\beta$-LG B, and $\beta$-LG $\mathrm{C}$. These traces were selected so that approximately equal loss of the native protein (peak 26) occurred from each variant: A) about $20 \%$ of the intact protein remaining and B) only 1 to $2 \%$ of the intact protein remaining. Selected peaks are labeled as shown in Figure 4 and Table 1.

Lys (Lys69-Lys70 and Lys100-Lys101) were rapidly cleaved at the Lys70-Ile71 and Lys101-Tyr102 bonds, respectively. Lys47-Pro48 was not cleaved at all, despite an earlier report (Otte et al., 1997). The Lys69Lys70 and Lys101-Lys102 bonds at the C-termini of peptides 2 and 9 were also cleaved slowly to give peptides 3 and 12 (Figures 6 and 7 and Table 1), but this was more of a peptidase activity than a protease activity. The remaining Lys-Lys, Lys135-Phe136, Lys77Ile78, Lys83-Ile84, and Lys91-Val92, were also cleaved slowly. However, there was an anomalous tryptic cleavage between Tyr20 and Ser21.

\section{DISCUSSION}

$\beta$-Lactoglobulin A was hydrolyzed faster than $\beta$-LG $\mathrm{B}$ or $\beta$-LG $\mathrm{C}$ (Figures 1 and 2) regardless of $\mathrm{pH}$ and temperature (Figures $3 \mathrm{~A}$ and $\mathrm{B}$ ), and it seems likely that the difference in loss of intact protein between the variants reflects the difference in the rates of hydrolysis of the initial bonds cleaved by the enzyme compared with those cleaved subsequently. The present results show that substantial changes in protein concentration make relatively small differences to the relative rates of hydrolysis of the 3 variants and that moderate in- 
Table 1. Peptide identification of tryptic hydrolysis of $\beta$-LG A, B, and C. The standard variant is considered to be $\beta$-LG B. (Reproduced from Creamer et al., accepted)

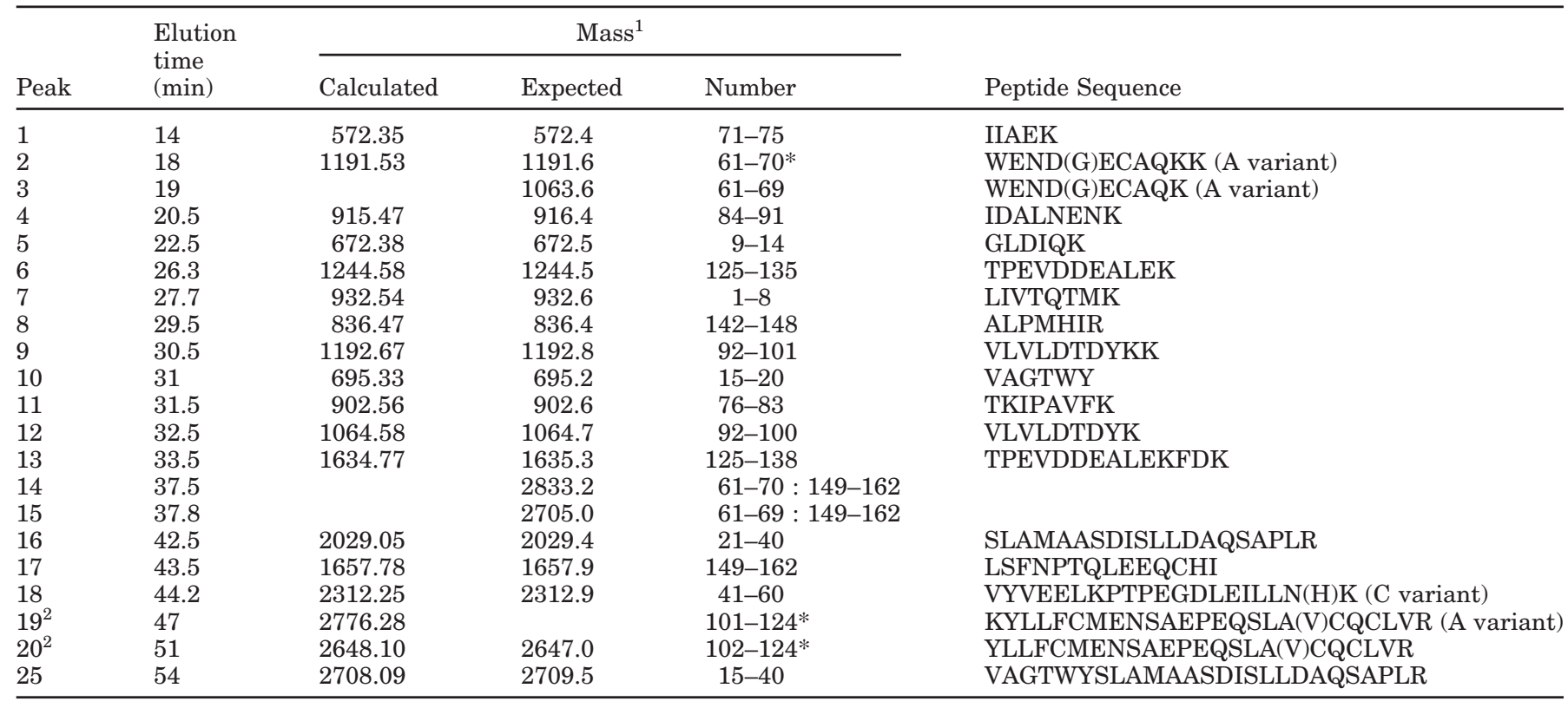

${ }^{1}$ Average mass.

${ }^{2}$ Observed only in reduced system.

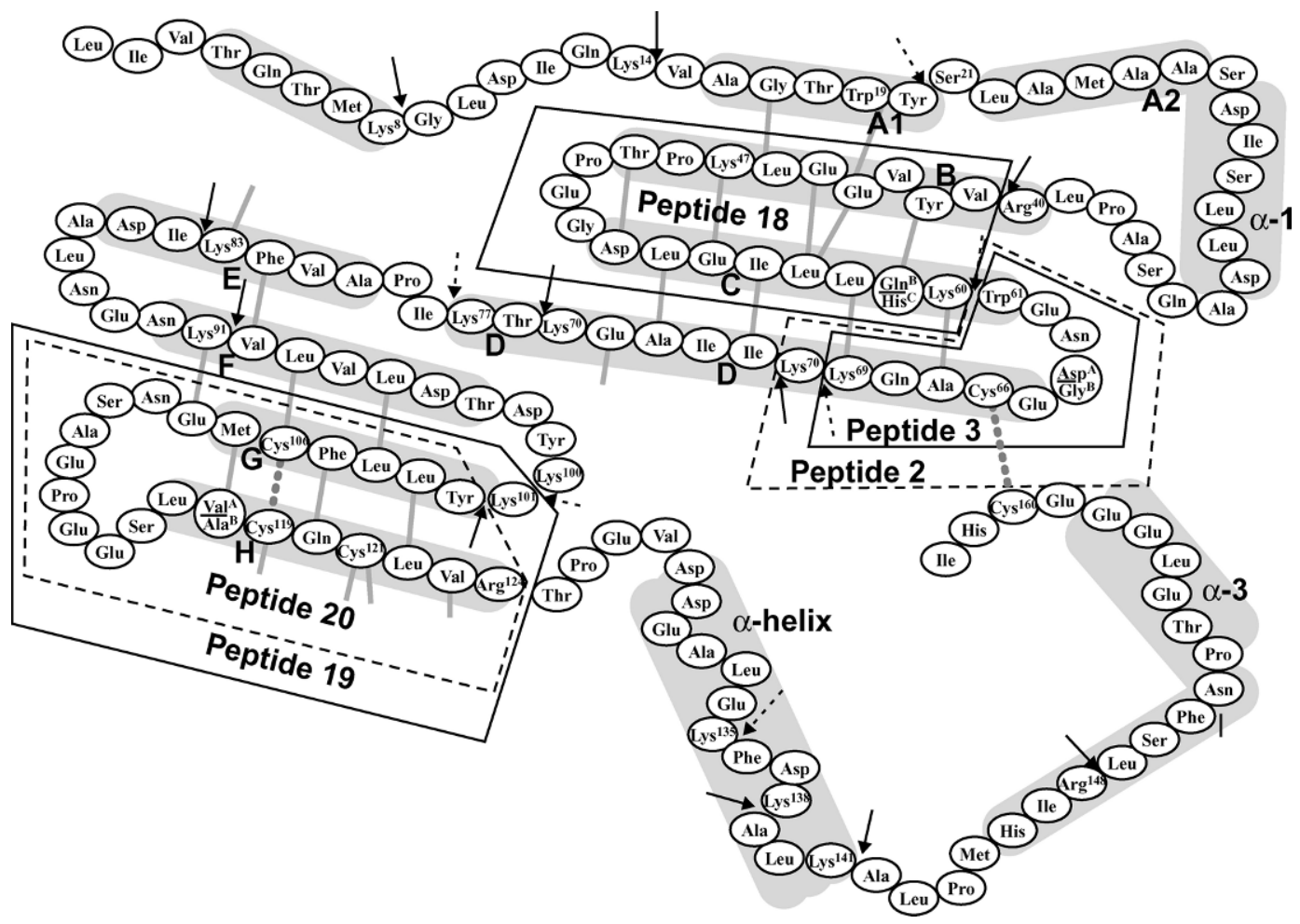

Figure 6. The sequences of $\beta$-LG A, $\beta$-LG B, and $\beta$-LG C and the secondary structural elements noted by Qin et al. (1999) for the lattice $\mathrm{Z}$ structure at $\mathrm{pH} 6$ are shown. The hydrolysis points are shown by means of small arrows; those with solid shafts indicate peptide bonds cleaved at the same rate (and determined by variant type), and the other arrows indicate the bonds cleaved more slowly and at the same rate, regardless of variant type. The reduced peptides (peaks 2, 3, 18, 19, and 20 in Figure 4) that were eluted at different times (Figure 5 ) are highlighted to indicate their positions within the secondary and tertiary structure of $\beta$-LG. 

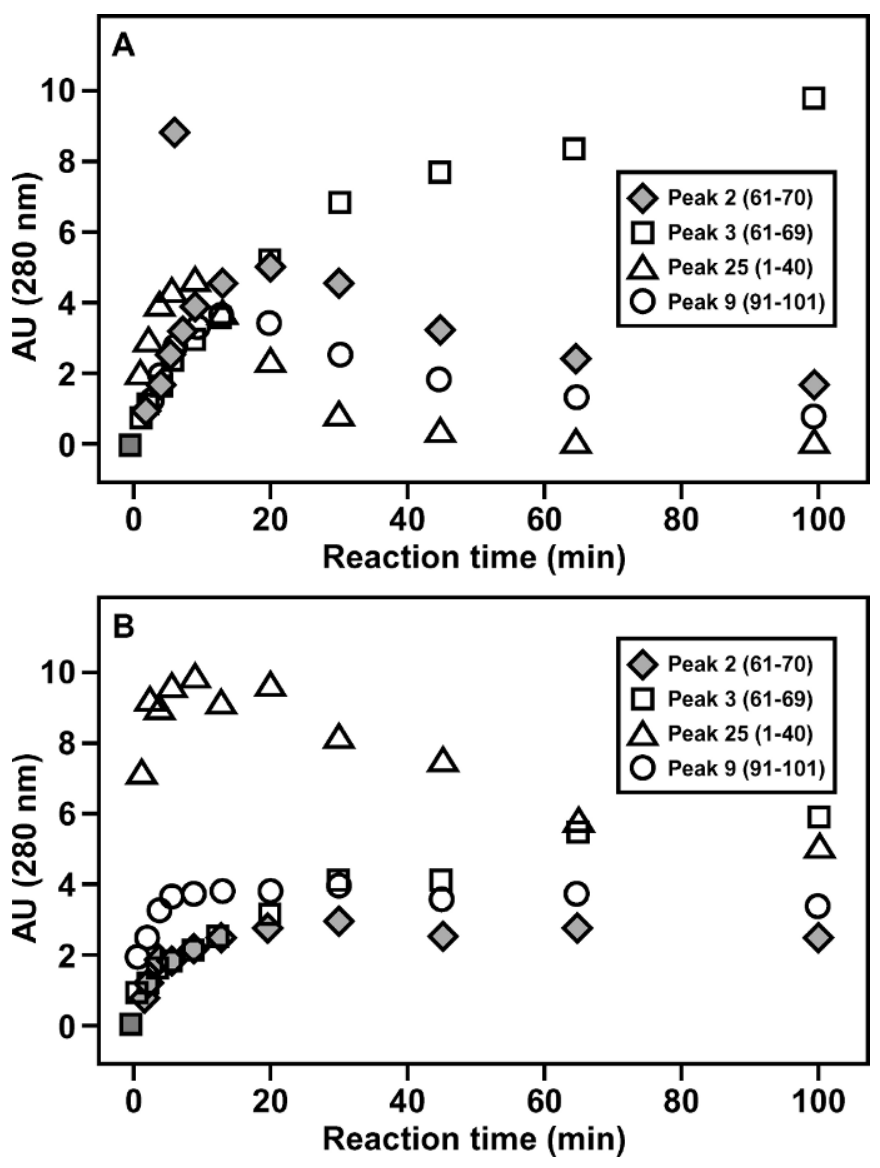

Figure 7. Comparison of selected peptides released from A) native and B) heated $\beta$-LG B. AU = absorbance unit. Drawn from the data of van Wanroij (2001).

creases in reaction $\mathrm{pH}$ (Figure 3A) and temperature (Figure 3B) decrease the differences between the rates of hydrolysis of $\beta$-LG A and $\beta$-LG B slightly. However, addition of the chaotropic solute urea altered the relative rate of hydrolysis of $\beta$-LG A compared with $\beta$-LG B or $\beta$-LG C, and all the reaction rates increased markedly (Figure 3C). In contrast, addition of palmitic acid decreased all the rates of hydrolysis, with that of $\beta$-LG A decreasing more than those of $\beta$-LG B or $\beta$-LG C (results not shown). Taken together, these results indicate that some structural feature in $\beta$-LG A is different from that in $\beta$-LG $\mathrm{B}$ or $\beta$-LG $\mathrm{C}$.

In recent years, the x-ray structures of the 3 variants (Bewley et al., 1997), but especially the A and B variants, have been determined (Qin et al., 1999; Oliveira et al., 2001), and they show relatively minor differences. Preliminary dynamics results (P. J. Edwards, 2004, personal communication) show that there appear to be some distinct differences between the solution structures of the $\mathrm{A}$ and $\mathrm{B}$ variants at low $\mathrm{pH}$. Heat denaturation studies show that the $\mathrm{A}, \mathrm{B}$, and $\mathrm{C}$ variant proteins differ in their susceptibility to higher temperatures (Manderson et al., 1998). Botelho et al. (2000) applied high pressures to the $\mathrm{A}$ and $\mathrm{B}$ variants and concluded that the $\mathrm{B}$ variant has a greater sensitivity to pressure than the A variant, probably as a consequence of the slightly larger cavity caused by the Val118Ala mutation. Jameson et al. (2002) considered that the hydrophobic cavity of $\beta$-LG has an important effect on the structural stability or denaturation of the protein. Jayat et al. (2004) modified the Cys121 residue and examined the structural consequences of replacing a side chain with a smaller side chain (Cys121Ser). It can be concluded that small changes in the primary structures, particularly in the components of the stable FGH motif (Figure 6), affect the flexibility of the tertiary structure close to Cys 119 and hence the reactivity of $\beta$ LG. No doubt the A to B variant change of Val to Ala is another example of this structural sensitivity.

The other structural difference between the A and B variants is the Asp64Gly (A to B) transformation. This change alters the net charge on $\beta-\mathrm{LG}$, which, in turn, alters the dimer-monomer dissociation equilibrium. Also it probably alters the conformation of the CD loop (Figure 6), which carries 3 acidic residues in the A variant, but only 2 acidic residues in the $\mathrm{B}$ variant. Xray crystallography was not able to show any differences among the variants. An NMR study is also unlikely to show differences, which may be observable only in a neutral aqueous environment. Consequently, the relative importance of the change at residues 64 and 118 can only be speculated. For example, Jameson et al. (2002) considered that the effect of heat denaturation as a function of temperature (Manderson et al., 1997) was different for the A and B variants because of 2 effects. The first effect, the shift in midpoint temperature, was probably caused by the change in net charge, and the second effect, the change in the slope of the temperature dependence of denaturation, was entropy related and was probably related to the water in the hydrophobic cavity. This effect was also noted by Botelho et al. (2000) in relation to pressure treatments.

It is of interest to compare these results from native $\beta$-LG B with those of a recent study, which measured the rates of peptide release from heated $\beta$-LG $\mathrm{B}$ (Creamer et al., submitted). In that study, the peptides were released from disulfide-bonded aggregates, and full release was achieved only after the large aggregates had been broken down. Not surprisingly, the most rapidly released peptides were close to the termini. Four examples (shown in Figure 7A) were chosen because the peptides contained Tyr and/or Trp, which could be measured quantitatively at $280 \mathrm{~nm}$ in the presence of other peptides. As shown earlier, 12 of the 18 trypsinsusceptible bonds in native $\beta$-LG $\mathrm{B}$ appear to cleave 
simultaneously. This is confirmed by the data shown in Figure 7A for the first 7 to 10 min (the peptide of peak 25 has a higher absorbance than any of the other peptides and thus appears to be released faster), but this is not the case for heated $\beta$-LG B.

The first example (peak 25) shows a very rapid release and a relatively slower disappearance for the heated sample (Figure 7B). The rapid release occurs partly because Arg is a preferred site for trypsin, and possibly because this region is no longer constrained by the native structure of the protein. Peak 9 (Val91Lys101) is also released more rapidly than in the native protein, whereas peak 2 appears to be released a little more slowly than in the native protein.

A different behavior is observed in the increase and subsequent decrease (by cleavage at Lys8-Gly9, Lys14Val15, and Tyr20-Ser21) of the N-terminal peptide Leu15-Arg40 (peak 25). Both this peptide and Val92Lys101 (peak 9) are released more slowly from native $\beta$-LG B (Figure 7A) than the heated protein (Figure 7B). It is also more rapidly hydrolyzed to smaller products. This very rapid release shows that the Arg40Val41 bond is less available to the enzyme in the native protein than in the heated $\beta$-LG $\mathrm{B}$, possibly because this bond is within a $\beta$-sheet and needs to be free of the constraints of the native structure.

The appearance of peaks 2 and 3 (Trp61-Lys70 and Trp61-Lys69, respectively) is initially at similar rates for both the heated and native proteins, showing that the Lys70-Ile71 and Lys69-Lys70 bonds are initially cleaved at comparable rates. However, cleavage of Lys70 from the peptide of peak 2, an aminopeptidase activity, is slower.

\section{CONCLUSIONS}

A number of trypsin-sensitive peptide bonds are hydrolyzed more rapidly in $\beta$-LG A than in $\beta$-LG $\mathrm{B}$ or $\beta$ LG $\mathrm{C}$, but many others are cleaved at the same rate for all variants. Higher temperature, addition of urea, and higher $\mathrm{pH}$ all increased the rate of reaction, but palmitic acid decreased the rate of reaction markedly. All of these treatments decreased the rate of hydrolysis of $\beta$-LG A relative to $\beta$-LG B but did not change the relative rates of hydrolysis of $\beta$-LG B and $\beta$-LG C. Identification of tryptic peptides allowed detailed comparison of the rates of hydrolysis between the $\beta$-LG genetic variants. Twelve bonds were cleaved significantly faster than the other 6 bonds, and the difference in the rates of cleavage was greater for $\beta$-LG A than for $\beta$-LG B or $\beta$-LG C. It is probable that the overall stabilities of the 3 variants influence the differences in the rates of cleavage and that these stabilities are affected by the differences in the solution structures of the 3 variants.

\section{ACKNOWLEDGMENTS}

We thank Anna Whitlock's foundation, Makarna Lindeqvist Foundation, Svenska Livsmedelstekniska föreningen, Lund University, the Foundation for Research, Science and Technology (Contracts DRI-801 and DRIX0201), the California State University Agricultural Research Initiative, and Dairy Management Inc. for the financial support that made this project possible. We also thank Mike Boland, Rose Motion, Darren Engelbretson, Carmen Norris, Garnett Davy, and Nicola Wallace for valuable assistance with this study.

\section{REFERENCES}

Bewley, M. C., B. Y. Qin, G. B. Jameson, L. Sawyer, and E. N. Baker. 1997. Bovine $\beta$-lactoglobulin and its variants: A three-dimensional structural perspective. Pages 100-109 in International Dairy Federation Special Issue 9702. Milk Protein Polymorphism. International Dairy Federation, Brussels, Belgium.

Botelho, M. M., V. L. Valente-Mesquita, K. M. G. Oliveira, I. Polikarpov, and S. T. Ferreira. 2000. Pressure denaturation of $\beta$-lactoglobulin. Different stabilities of isoforms A and B, and an investigation of the Tanford transition. Eur. J. Biochem. 267:2235-2241.

Caessens, P., W. F. Daamen, H. Gruppen, S. Visser, and A. G. J. Voragen. 1999a. $\beta$-lactoglobulin hydrolysis. 2. Peptide identification, SH/SS exchange, and functional properties of hydrolysate fractions formed by the action of plasmin. J. Agric. Food Chem. 47:2980-2990.

Caessens, P. W., S. Visser, H. Gruppen, and A. G. J. Voragen. 1999b. $\beta$-Lactoglobulin hydrolysis. 1. Peptide composition and functional properties of hydrolysates obtained by the action of plasmin, trypsin, and Staphylococcus aureus V8 protease. J. Agric. Food Chem. 47:2973-2979.

Chen, S. X., H. E. Swaisgood, and E. A. Foegeding. 1994. Gelation of $\beta$-lactoglobulin treated with limited proteolysis by immobilized trypsin. J. Agric. Food Chem. 42:234-239.

Chevalier, F., J. M. Chobert, M. Dalgalarrondo, Y. Choiset, and T. Haertle. 2002. Maillard glycation of $\beta$-lactoglobulin induces conformation changes. Nahrung-Food 46:58-63.

Cho, Y.-H. 2000. Effect of bound ligands and $\kappa$-casein on the denaturation of bovine $\beta$-lactoglobulin. Ph.D. Thesis, Massey University, Palmerston North, New Zealand.

Creamer, L. K. 1995. Effect of sodium dodecyl sulfate and palmitic acid on the equilibrium unfolding of bovine $\beta$-lactoglobulin. Biochemistry 34:7170-7176.

Creamer, L. K., A. Bienvenue, H. Nilsson, M. Paulsson, M. Van Wanroij, E. K. Lowe, S. G. Anema, M. J. Boland, and R. JiménezFlores. Heat-induced redistribution of disulfide bonds in milk peptides: Part 1: Bovine $\beta$-lactoglobulin. J. Agric. Food Chem (accepted).

Dalgalarrondo, M., E. Dufour, C. Bertrandharb, J. M. Chobert, and T. Haertle. 1992. Purification and characterization of 2 porcine $\beta$-lactoglobulin variants by $\mathrm{NaCl}$ salting-out and reversed phaseHPLC. Lait 72:35-42.

Dufour, E., M. Dalgalarrondo, and T. Haertle. 1994. Limited proteolysis of $\beta$-lactoglobulin using thermolysin. Effects of calcium on the outcome of proteolysis. Int. J. Biol. Macromol. 16:37-41.

Farrell, H. M. J., R. Jiménez-Flores, G. T. Bleck, E. M. Brown, J. E. Butler, L. K. Creamer, C. L. Hicks, C. M. Hollar, K. F. Ng-KwaiHang, and H. E. Swaisgood. 2004. Nomenclature of the proteins of cows' milk - sixth revision. J. Dairy Sci. 87:1641-1674.

Hill, J. P., M. J. Boland, L. K. Creamer, S. G. Anema, D. E. Otter, G. R. Paterson, R. Lowe, R. L. Motion, and W. C. Thresher. 1996. Effect of the bovine $\beta$-lactoglobulin phenotype on the properties of $\beta$-lactoglobulin, milk composition, and dairy products. Pages 281-294 in Macromolecular Interactions in Food Technology. 
ACS Symposium Series 650. American Chemical Society, Washington, DC.

Huang, X. L., G. L. Catignani, and H. E. Swaisgood. 1994a. Comparison of the size and rate formation of peptides released by limited proteolysis of $\beta$-lactoglobulins A and B with immobilized trypsin. J. Agric. Food Chem. 42:1281-1284.

Huang, X. L., G. L. Catignani, and H. E. Swaisgood. 1994b. Relative structural stabilities of $\beta$-lactoglobulins A and B as determined by proteolytic susceptibility and differential scanning calorimetry. J. Agric. Food Chem. 42:1276-1280.

Huang, X. L., G. L. Catignani, and H. E. Swaisgood. 1996. Improved emulsifying properties of $\beta$-barrel domain peptides obtained by membrane-fractionation of a limited tryptic hydrolysate of $\beta$-lactoglobulin. J. Agric. Food Chem. 44:3437-3443.

Imre, T., F. Zsila, and P. T. Szabo. 2003. Electrospray mass spectrometric investigation of the binding of cis-parinaric acid to bovine $\beta$-lactoglobulin and study of the ligand-binding site of the protein using limited proteolysis. Rapid Commun. Mass Spectrom. 17:2464-2470.

Jameson, G. B., J. J. Adams, and L. K. Creamer. 2002. Flexibility, functionality and hydrophobicity of bovine $\beta$-lactoglobulin. Int. Dairy J. 12:319-329.

Jayat, D., J. C. Gaudin, J. M. Chobert, T. V. Burova, C. Holt, I. McNae, L. Sawyer, and T. Haertle. 2004. A recombinant C121S mutant of bovine $\beta$-lactoglobulin is more susceptible to peptic digestion and to denaturation by reducing agents and heating. Biochemistry 43:6312-6321.

Manderson, G. A., M. J. Hardman, and L. K. Creamer. 1997. Spectroscopic examination of the heat-induced changes in $\beta$-lactoglobulin A, B and C. Pages 204-211 in International Dairy Federation Special Issue 9702. Milk Protein Polymorphism. International Dairy Federation, Brussels, Belgium.

Manderson, G. A., M. J. Hardman, and L. K. Creamer. 1998. Effect of heat treatment on the conformation and aggregation of $\beta$-lactoglobulin A, B, and C. J. Agric. Food Chem. 46:5052-5061.

Maynard, F., A. Weingand, J. Hau, and R. Jost. 1998. Effect of highpressure treatment on the tryptic hydrolysis of bovine $\beta$-lactoglobulin AB. Int. Dairy J. 8:125-133.

McLean, D. M., E. R. B. Graham, R. W. Ponzoni, and H. A. McKenzie. 1984. Effects of milk protein genetic variants on milk yield and composition. J. Dairy Res. 51:531-546.

Monnot, M. 1964. Etude cinetique de l'hydrolyse tryptique des lactoglobulines A et B. Biochim. Biophys. Acta 93:31-39.
Monnot, M., and J. Yon. 1964. Etude cinetique de l'hydrolyse tryptique des lactoglobulines $\mathrm{A}$ et $\mathrm{B}$ en fonction du $\mathrm{pH}$. Biochim. Biophys. Acta 92:105-110.

Motion, R. L., and J. P. Hill. 1994. A comparison of the tryptic and chymotryptic hydrolysis of $\beta$-lactoglobulin $\mathrm{A}, \mathrm{B}$ and $\mathrm{C}$ variants. Page 122 in 24th Int. Dairy Congr., Melbourne, Australia, 1822 September 1994.

Mulvihill, D. M., and J. E. Kinsella. 1987. Gelation characteristics of whey proteins and $\beta$-lactoglobulin. Food Technol. 41:102-111.

Nilsson, H. 2000. Hydrolysis of $\beta$-lactoglobulin A, B and C with trypsin. Thesis, Lund University, Lund, Sweden.

Oliveira, K. M. G., V. L. Valente-Mesquita, M. M. Botelho, L. Sawyer, S. T. Ferreira, and I. Polikarpov. 2001. Crystal structures of bovine $\beta$-lactoglobulin in the orthorhombic space group C222(1). Structural differences between genetic variants A and B and features of the Tanford transition. Eur. J. Biochem. 268:477-483.

Otte, J., M. Zakora, K. B. Qvist, C. E. Olsen, and V. Barkholt. 1997. Hydrolysis of bovine $\beta$-lactoglobulin by various proteases and identification of selected peptides. Int. Dairy J. 7:835-848.

Qin, B. Y., M. C. Bewley, L. K. Creamer, E. N. Baker, and G. B. Jameson. 1999. Functional implications of structural differences between variants $\mathrm{A}$ and $\mathrm{B}$ of bovine $\beta$-lactoglobulin. Protein Sci. 8:75-83.

Schilling, B., R. H. Row, B. W. Gibson, X. Guo, and M. M. Young. 2003. MS2Assign, automated assignment and nomenclature of tandem mass spectra of chemically crosslinked peptides. J. Am. Soc. Mass Spectrom. 14:834-850.

Schmidt, D. G., and B. W. van Markwijk. 1993. Enzymatic hydrolysis of whey proteins. Influence of heat treatment of $\alpha$-lactalbumin and $\beta$-lactoglobulin on their proteolysis by pepsin and papain. Neth. Milk Dairy J. 47:15-22.

Turgeon, S. L., S. F. Gauthier, D. Mollé, and J. Léonil. 1992. Interfacial properties of tryptic peptides of $\beta$-lactoglobulin. J. Agric. Food Chem. 40:669-675.

van Wanroij, M. 2001. Hydrolysis of heated $\beta$-lactoglobulin with trypsin. M.S. Thesis, Wageningen University, The Netherlands.

Van Willige, R. W. G., and R. J. FitzGerald. 1995. Tryptic and chymotryptic hydrolysis of $\beta$-lactoglobulin $\mathrm{A}, \mathrm{B}$ and $\mathrm{AB}$ at ambient and high pressure. Milchwissenschaft 50:183-186.

Verheul, M., J. S. Pedersen, S. Roefs, and K. G. de Kruif. 1999. Association behavior of native $\beta$-lactoglobulin. Biopolymers 49:11-20. 